\title{
BROWN-HEADED COWBIRD PARASITIZES UPLAND SANDPIPER NEST
}

STEPHEN K. DAVIS ${ }^{1}$, JAMES R. DUNCAN ${ }^{2}$, KURT M. MAZUR $^{3}$, and PATRICIA A. DUNCAN ${ }^{4}$ Saskatchewan Wetland Conservation Corporation, 202-2050 Cornwall Street, Regina, SK S4P 2K5. Phone (306) 787-0711,2, 4 Box 253 Balmoral, MB ROC OHO. ${ }^{3}$ Partners in Flight Manitoba, Box 24, 200 Saulteaux Crescent, Winnipeg, MB R3J 3W3

The Brown-headed Cowbird (hereafter cowbird) is an obligate brood parasite that lays its eggs in the nests of other birds, the hosts. Cowbirds are known to have parasitized over 220 species of birds, of which at least 144 species have reared cowbird young ${ }^{3}$. Although cowbirds typically parasitize passerine hosts ${ }^{7}$, occasionally they lay in nests of non-passerine species. Friedmann and Kiff ${ }^{3}$ documented parasitism on such unusual species as Ferruginous Hawk, California Gull, Redheaded Woodpecker and Ruby-throated Hummingbird. Equally unusual are the documented instances of cowbirds parasitizing species with precocial young, such as Blue-winged Teal and Virginia Rail ${ }^{3}$. We document the fourth record of Brown-headed Cowbird parasitism on the Upland Sandpiper, a precocial species.

On 6 July 1991, while searching for Ferruginous Hawk nests in a pasture southeast of Pipestone, Manitoba, we flushed an Upland Sandpiper from its nest. Typical of Upland Sandpipers ${ }^{2}$, the adult vocalized upon leaving the nest and gave an injury-feigning distraction

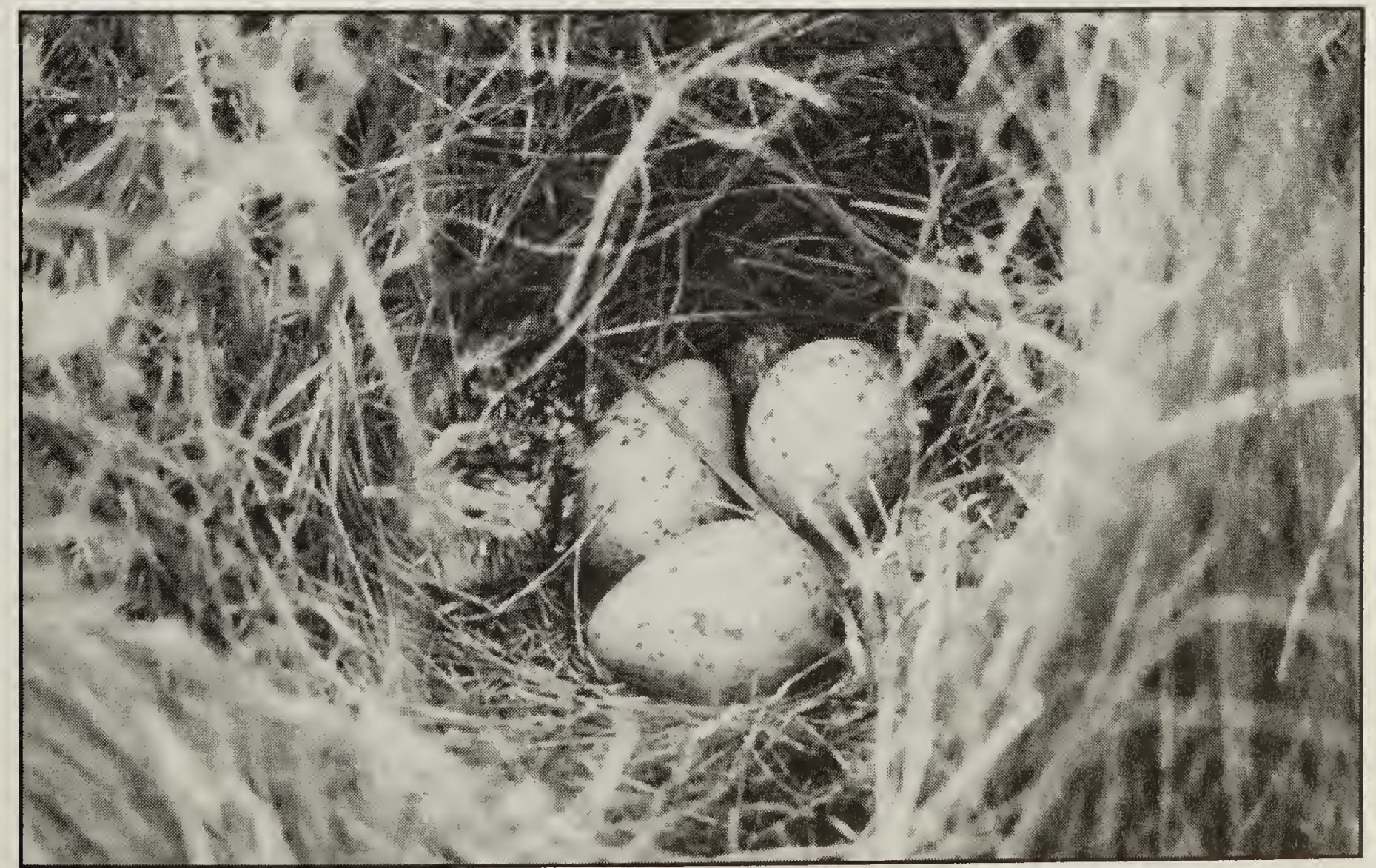

Figure 1. Upland Sandpiper nest with a newly hatched young, three sandpiper eggs, and a cowbird egg. 
display. Upon inspecting the nest we were surprised to see one newlyhatched sandpiper, three pipped sandpiper eggs, and a cowbird egg lying near the inner edge of the nest (Fig. 1). We returned to the site two days later but were unable to relocate the nest to confirm the fate of the cowbird egg.

Cowbird eggs have been recorded infrequently in nests of other shorebird species: Killdeer (two instances), Spotted Sandpiper (five instances), and Wilson's Phalarope (three instances) ${ }^{3}$. Friedmann ${ }^{4}$ reported an Upland Sandpiper nest in Minnesota that contained four host eggs, and one cowbird egg that was partially buried in the bottom of the nest. Two additional Upland Sandpiper nests from North Dakota contained three host eggs along with single cowbird eggs ${ }^{5,6}$. Because Upland Sandpipers typically lay four eggs ${ }^{1,6}$, Higgins ${ }^{5}$ suggested that the cowbird may have removed a sandpiper egg from the nest. In both cases, however, it was not known for certain whether the sandpipers laid only three eggs. Furthermore, it is unlikely that a cowbird could remove such a large egg (S. G. Sealy pers. comm.).

Cowbird parasitism on inappropriate hosts is interesting in itself, but one wonders why a cowbird would lay an egg in a nest where there is no chance for the egg to survive. We offer three possible explanations for this behaviour. First, cowbirds may opportunistically "dump" their eggs in inappropriate nests when no suitable hosts are available at the time of egg laying. Second, the high fecundity of some cowbird populations (over 40 eggs laid per breeding season ${ }^{8}$ ) may allow cowbirds to parasitize novel hosts in an attempt to assess host suitability, at a low reproductive cost. Although the mechanism is unknown, cowbirds may have employed such a strategy as they encountered new hosts during their range expansion. Third, this behaviour may reflect variation in the effectiveness of individual cowbirds within the population, that is, even cowbirds make mistakes.

\section{Acknowledgements}

Comments by Spencer G. Sealy, D. Glen McMaster and Robert W. Nero greatly improved the manuscript.

\section{Bibliography}

1. BENT, A.C. 1929. Bartramia longicauda (Bechstein) Upland Plover. U.S. Natl. Mus. Bull. 146:55-69.

2. EHRLICH, P.R., D.S. DOBKIN, and D. WHEYE. 1988. The Birder's Handbook. Simon and Schuster Inc., New York.

3. FRIEDMANN, H. and L.K. KIFF. 1985. The parasitic cowbirds and their hosts. Proc. West. Found. Vert. Zool. 2:26-302.

4. FRIEDMANN, H. 1963. Host relations of the parasitic cowbirds. U.S. Nat. Mus. Bull. 233:1-276.

5. HIGGINS, K.F. 1971. Note. Prairie Nat. 3:79.

6. HIGGINS, K.F. and L.M. KIRSCH. 1975. Some aspects of the breeding biology of the Upland Sandpiper in North Dakota. Wilson Bull. 87:96-102.

7. LOWTHER, P. 1993. Brown-headed Cowbird (Molothrus ater). In The Birds of North America, No. 47 (A. Poole and F. Gill eds.). The Academy of Natural Sciences, Philadelphia, Pennsylvania and The American Ornithologists' Union, Washington, D.C.

8. SCOTT, D.M. and C.D. ANKNEY. 1980. Fecundity of the Brown-headed Cowbird in southern Ontario. Auk 97:677-683. 